\title{
Taxonomic notes on non-domiciliary Periplaneta species from the Ryukyus, Taiwan, Hong Kong and Thailand
}

\author{
Syoziro AsAHINA* \\ Department of Medical Entomology, National Institute of Health, \\ Shinagawa-ku, Tokyo 141, Japan
}

(Received: January 10, 1980)

\begin{abstract}
The undescribed male insect of Periplaneta suzukii is described, and six Taiwanese representatives of wild Periplaneta are described and illustrated. Records of each one species from Hong Kong and Thailand are also added. Mention is made with regard to the difference between treated Periplaneta species and an African genus Cartoblatta Shelford.
\end{abstract}

In 1977 I described a peculiar short-winged Periplaneta species, P. suzukii, from Amamioshima in the Ryukyus. Further material including unknown male sex of the same species were subsequently obtained, and it was revealed that the male insect posesses well developed both wings with flight ability.

In this paper the male insect of $P$. suzukii is described and taxonomic notes are given to several allied species very insufficiently known from Taiwan. The other related species taken from Hong Kong and Thailand are also dealt with on this occasion.

The newly designated type specimens will be deposited in the collection of the Medical Entomology Department, National Institute of Health, Tokyo.

\section{Periplaneta suzukii Asahina}

Periplaneta suzukii Asahina, 1977, p. 101, Fig. 1 (forewing), Fig. 2 (supra-anal plate) 우 “ 1 우 Katoku, Setouchi-machi (Amami-oshima), 20.VI.1975, under a rotten wood."

Material examined :

1 우 (Holotype) Katoku, Amami-oshima, 20.VI.1975, leg. H. Suzuki; $1 \hat{o}$ (Allotype) 3 ㅇ ditto, 18.IX.1976, bred in laboratory in Tokyo; 1 ㅇ Komi, Iriomote

* 朝比奈正二郎: 国立予防衛生研究所衛生昆虫部 （干141 東京都品川区上大崎 2-10-35）
Island, 16.VII.1976, leg. S. Asahina; 1 ô Komi, Iriomote Island, 16. V.1977, leg. S. Asahina; 1 ㅇ Komi, Iriomote Island, 17. V .1977, leg. S. Asahina ; Larvae from Amami-oshima, Ishigaki Island and Iriomote Island.

o Allotype: Body length $24 \mathrm{~mm}$, forewing length $24 \mathrm{~mm}$. A typical Periplanetan insect; when closed the wing apices exceeding the end of abdomen. Body light brown, much paler against dark brownish female.

Head pale brownish, the upper part above the bases of antennae deep brownish, the ocellar spots whitish.

Prothoracic tergite fairly broad, almost ellipsoid, no distinct depression on the surface.

Forewing uniformly pale brownish, hindwing the same colour anteriorly but almost hyaline posterior to the plical vein.

Legs pale brownish, femora broad, the arolia poorly developed.

Abdominal tergites pale brownish, first tergite with a median tuft of hairs covering the secretory pit, posterior tergites $6-10$ are deeper in colour.

Supra-anal plate broadly divided with round lobes (Figs. 19, 21). End of hypandrium rather squarely cut (Figs. 20, 22), styli long. Apex of left phallosome sharply pointed with a minute recurved hook at the base 
(Fig. 23). Gizzard in the proventriculus is as Figs. 30, 31 .

A male specimen taken from a decaying wood in Iriomote Island is slightly larger in size, body $25 \mathrm{~mm}$, forewing $27 \mathrm{~mm}$, but is quite same in the other characters with those from Amami-oshima. Additional females from Amami-oshima and Iriomote Island were studied and the shape of their wings are illustrated in Figs. 24-27.

This seems to be a jungle forest insect, the adults seem to appear in May and June season, but the male insects are very scarce and difficult to capture with flight activity. The immature insects are not seldom in the same habitat.

Distribution: Endemic to the Ryukyus, Amami-oshima, Iriomote Island, and Ishigaki Island. From the last locality only one larval insect was taken.

\section{Periplaneta formosana Karny}

Periplaneta pallipalpis: Shiraki 1906 (nec Serville 1839), p. 4 "Nur ein Exemplare $(\delta)$ in der Sammlung von Herrn Dr. S. Matsumura aus Formosa (Juli)"

Periplaneta formosana Karny, 1915, pp. 96-

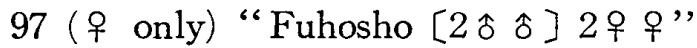

Periplaneta formosana: Shiraki, 1931, p. 180 Cartoblatta formosana: Princis, 1966b, p. 511 "Formosa"

Material examined: 1 ㅇ (Lectotype) Fuhosho, Formosa, Sauter, VII.1909, Karny det., Typus, "Periplaneta formosana Karny," "K. Princis 1961 "; $1 \hat{o}$ (Allotype!) "P. pallipalpis," Formosa, T. Uchida, Taihoku, 22. VI.1925, Takahashi (Coll. Hokkaido Univ.); 1 s "P. pallipalpis," Ranrun, 8.VII.1925, Formosa, T. Uchida, H. Kono, Y. Miwa (Coll. Hokkaido Univ.); 1 o Koshun, 6. VII.1906, Formosa, Matsumura, " $P$. pallipalpis."

As was already mentioned by Asahina (1967) the original male insect of this species was an Epilamprid, Rhabdoblatta takahashii Asahina (1967), and only the female remained in Blattidae. In 1961 Princis examined the type series and labelled one of the type females to be the lectotype (Figs. 38, 39), and later, in his Catalogue (1966b), Princis placed this species in Cartoblatta of Blattidae. I have examined the lectotype and accepted
Princis' type designation but now feel some doubt in selecting the male specimen for this species from Taiwan. However, from the body size and broader distribution I selected a series of long-winged males as listed above. The allotype male specimen now selected is a long-winged, pale brownish insect closely allied to that of $P$. suzukii.

$\hat{o}$ : Length of body $23 \mathrm{~mm}$, forewing $22 \mathrm{~mm}$.

Head shining pale brownish, top of head above the level of ocellar spots deep brownish.

Prothoracic tergite broad, broadest at the level posterior to the middle length, almost smoothly surfaced without distinct depression.

Forewings light brownish, hindwings the same colour anteriorly to the plical vein, posteriorly of which entirely hyaline.

Tergite of first abdominal segment with a secretory pit and hairs, posterior abdominal tergites slightly deeper in colour but not so distinctly as in the preceding species.

Supra-anal plate as Figs. 32, 35, posterior margin with lateral angles and a median incision. Hypandrium as Figs. 33, 35, almost flatly cut, with long styli. Left phallosome ending in a round head with a minute recurved hook at the base (Figs. 34, 36, 37).

\section{Periplaneta sp.}

Material examined: $1 \hat{\text { o }}$ (alcoholic) Wulai, Formosa, 7.VII.1961, leg. T. Shirozu.

This single male specimen is rather problematical. The body has been crushed and kept in alcohol. The body about $28 \mathrm{~mm}$, forewing length $27 \mathrm{~mm}$. General body coloration brownish, a little deeper than that of the preceding species.

Head brownish, prothoracic tergite the same colour but the marginal area deeper. In this alcoholic specimen the surface shows irregular markings as shown in the figure (Fig. 40).

Wings chestnut brown, posterior area of the hindwing paler. Arolia between the tarsal claws are well developed.

Abdomen with a secretory pit at the center of the first segment. Distal segments deeper in colour on the dorsum.

Supra-anal plate allied to that of formosana, but broader and without median incision. Hypandrium flatly produced and very slightly bilobed. The styli are very long 

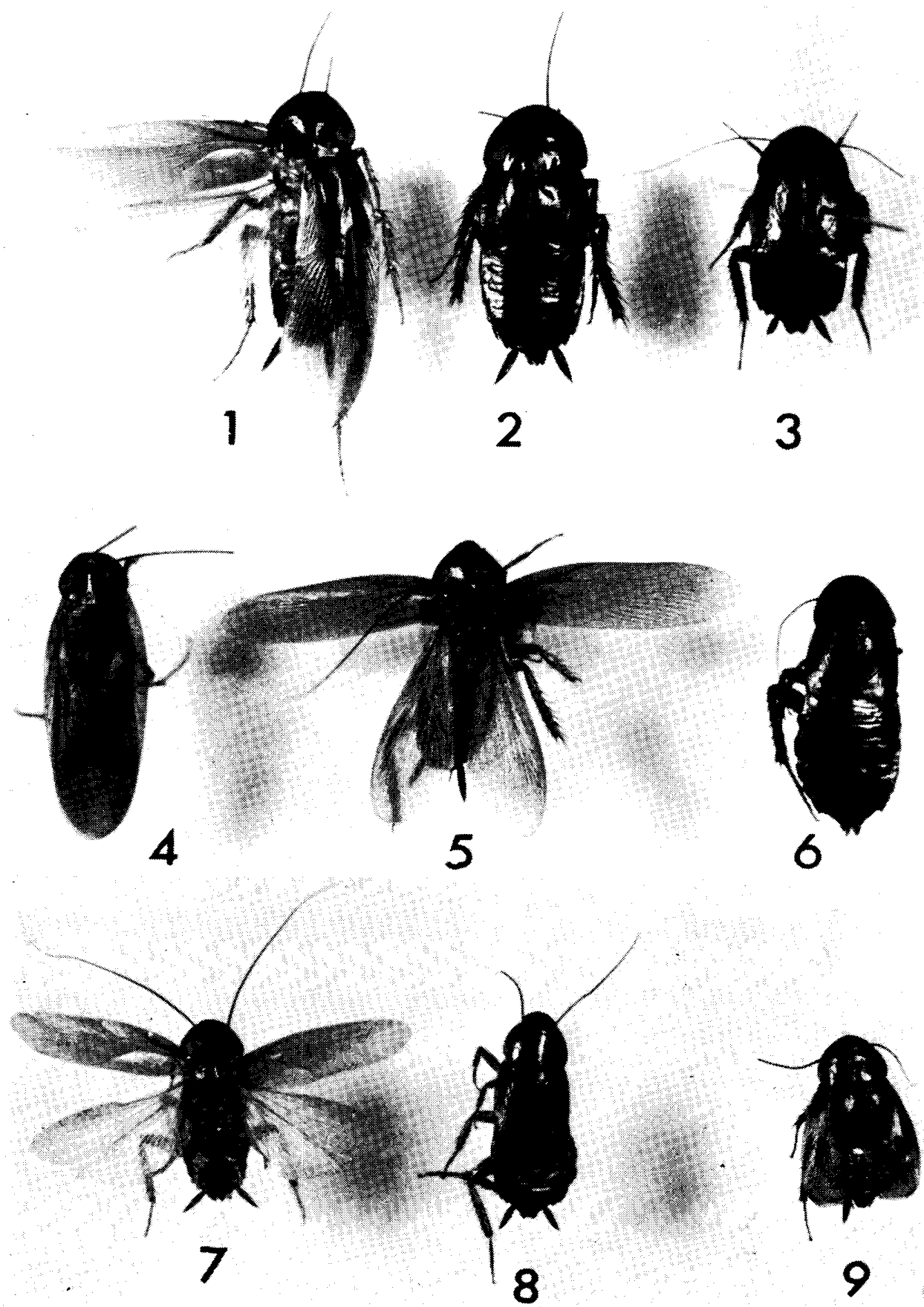

Figs. 1-3 Periplaneta suzukii Asahina, The Ryukyus

1: $\hat{o}$ (Allotype) Amami-oshima, 2: 우 Komi, Iriomote Island, 3: 우 (Holotype) Amamioshima

Fig. 4 Periplaneta arisanica Shiraki $\$$, Fen-ch'i-hu, Taiwan

Figs. 5, 6 Periplaneta formosana Karny, Taiwan

5: 소 (Allotype) Koshun, 6: 우 (Hololectotype) Fuhosho, leg. Sauter

Figs. 7-9 Periplaneta karnyi (Shiraki)

7: 우 (Allotype) Koshun, 8: 우 Koshun, 9: 오 (Holotype) Taihanroku, Sauter leg. 

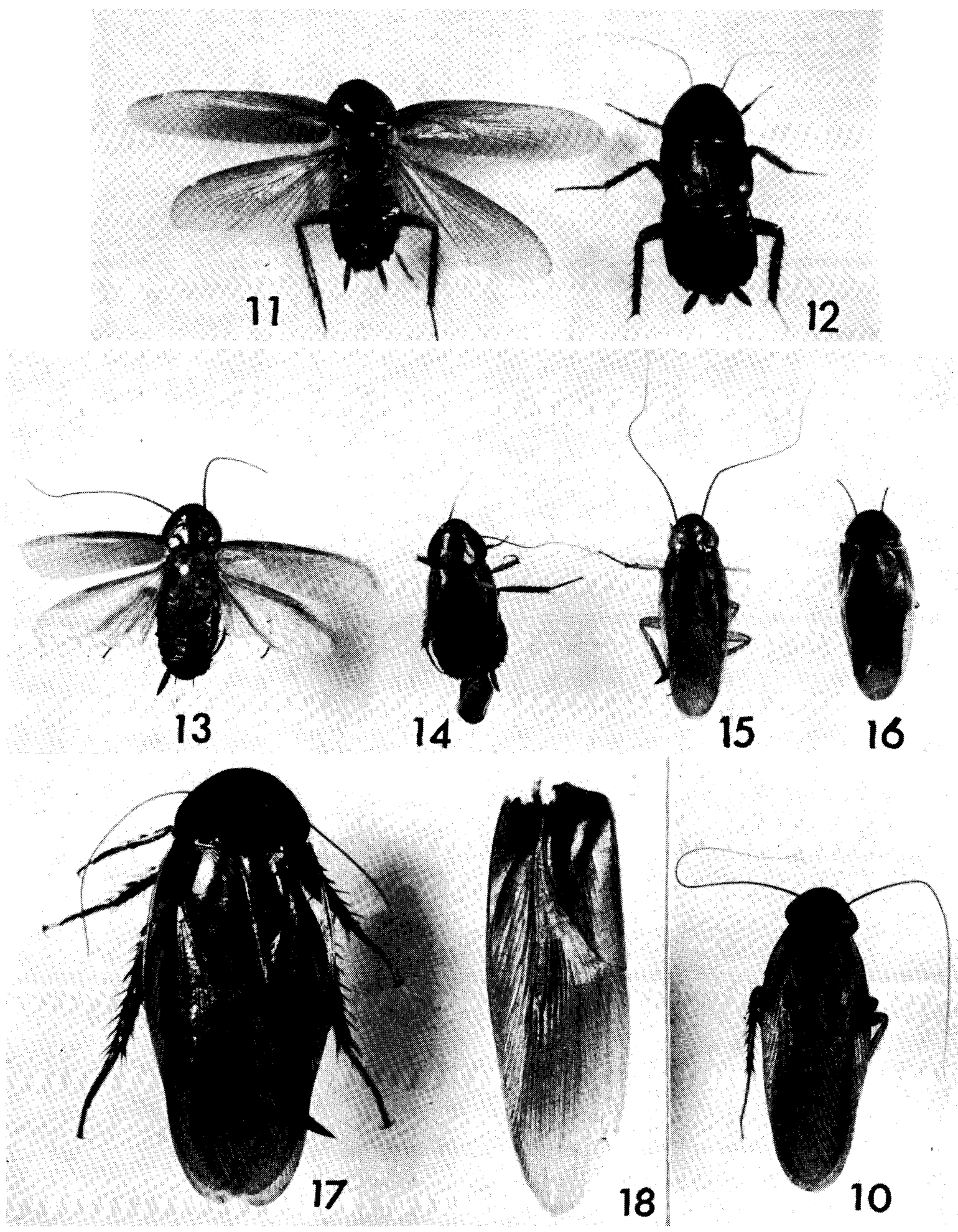

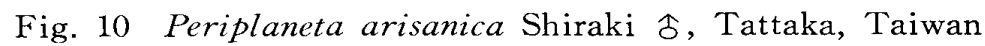

Figs. 11-12 Periplaneta ceylonica Hanitsch, Hong Kong, leg. J. D. Romer 11: 今 Hong Kong, 12: 우 (Allotype) Peak, Hong Kong

Figs. 13-16 Periplaneta floweri Hanitsch, Thailand 13: 今 Chiengmai, 14: 오 (Allotype) Chiengmai

Figs. 15, 16 Periplaneta karnyi (Shiraki)

15: 今 Kanchanaburi, Thailand, 16: 今 Cap St. Jacques, S. Vietnam

Figs. 17-18 Periplaneta banksi Hanitsch, Taiwan

17 : 우 Fuhosho, leg. Sauter, 18: 웅 (?) Forewing, Kenting, leg. Fukuhara 
(Figs. 41, 42).

The end of left phallosome as Fig. 43, very much allied to that of the preceding species, but the end is abbreviated with a round head. The gizzard armature is illustrated in Fig. 44.

Remarks: Since only a single imperfect alcoholic specimen was available no name is given for this species. It is impossible to decide if this is the real male insect of formosana or merely an individual variation of it.

\section{Periplaneta uenoi sp. nov.}

Material examined: $1 \hat{\delta}$ (Holotype) Wushe (Musha), Nan-t'ou Hsien, 14.VI.1961, leg. S. Ueno.

A middle-sized deep brownish species, superficially allied to the preceding two species, but decidedly distinct from them in the structure of supra-anal plate. Body $20 \mathrm{~mm}$, forewing $23 \mathrm{~mm}$, entirely deep brownish in colour.

Head shining brown, paler in labrum and anteclypeus, ocellar spots light yellowish. Prothoracic tergite entirely deep brownish,
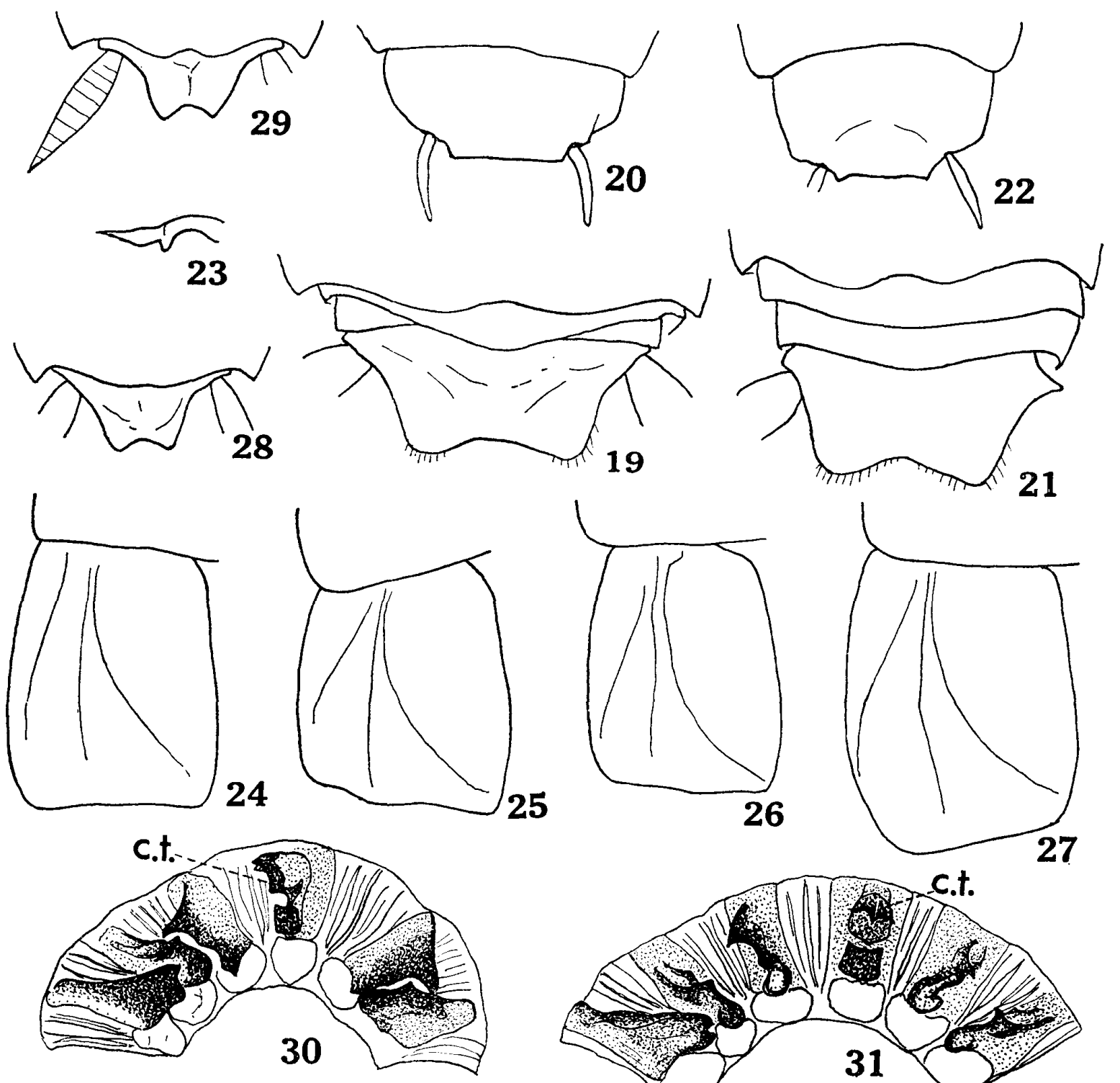

\section{5}
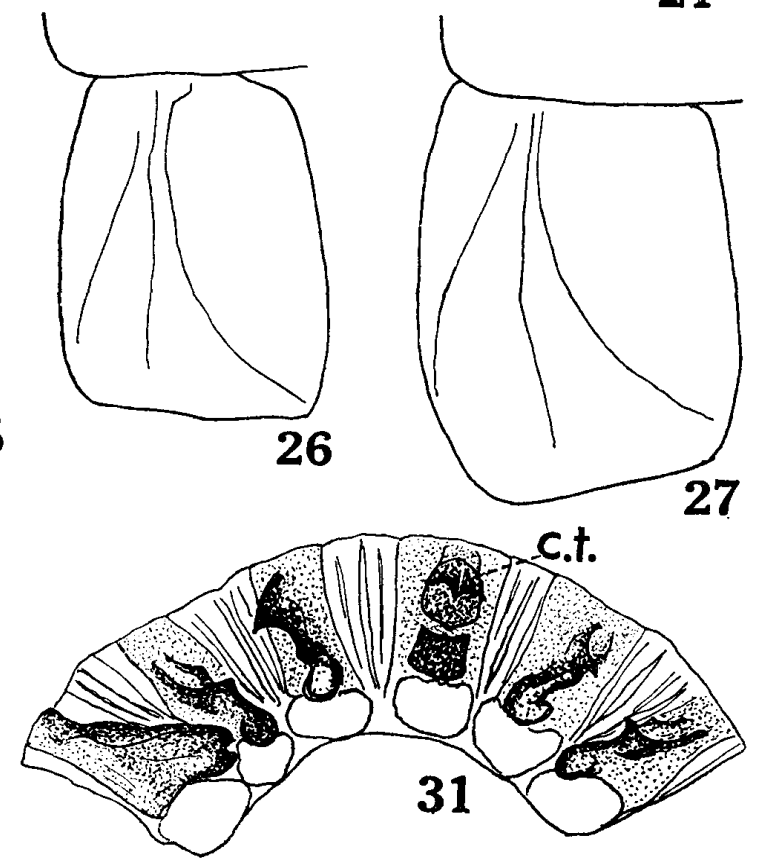

Figs. 19-31 Periplaneta suzukii, 今 Amami-oshima, dried specimens $(19,20,23-26,28)$, Amami-oshima, KOH treated specimens $(21,22,30)$, 우 Iriomote specimen $(27,29,31)$ 19, 21 : Supra-anal plate, 20, 22: 令 Hypandrium, 23: Apex of left phallosome, 24-27: 우 Left forewings, 28, 29: 우 Supra-anal plate, 30,31: Gizzard armature (c.t.: constricted tooth) 
broadest at the middle, surface slightly depressed posterolaterally.

Forewings deep brownish, hindwing paler with posterior hyaline area. Abdomen with a usual secretory pit at the middle of the first segment. Distal abdominal segments deep brown.

Supra-anal plate very much specialized with median longitudinal furrow (Fig. 45). Hypandrium broadly rounded with long styli (Fig. 46).

The end of left phallosome as Fig. 47, rather allied to that of formosanus.

Remarks: It is impossible to decide if this is, only because of its deep brownish coloration, the real male insect of formosanus.

\section{Periplaneta arisanica Shiraki}

Periplaneta arisanica Shiraki, 1931, pp. 180181, Fig. 3 (o forewing and abdominal end). $\delta$ \& "Formosa-Arisan, (IV)"

Cartoblatta arisanica: Princis, 1966b, p. 511 "nur 우 (nec $\hat{o}=$ Cartoblatta formosana, Periplaneta)"

Material examined: $2 \hat{\text { t }}$ Tattaka, Taiwan, 1.VI.1965, leg. T. Shirozu; 1 ô Fenchihu, $1370 \mathrm{~m}$, Chia-i Hsien, Taiwan, 11. IV.1965, leg. R. Kano; 1ô Punkiko, Taiwan, 18.V.1968, Coll. Tokyo Agr. Univ.; 1\} Sungkan, Central Taiwan, 9. V.1971, N. Fukuhara, Coll. N. I. Agr. Sci.

A rather slender pale brownish species. In general view these are allied to $P$. formosana but smaller and delicately built with shorter prothoracic tergite.

$\hat{\delta}$ Body $18 \mathrm{~mm}-20 \mathrm{~mm}$, forewing length $19-21 \mathrm{~mm}$ (1 $\hat{o} 23 \mathrm{~mm}$ )

Head entirely brownish, only ocellar spots pale yellow. Prothoracic tergite broad, not strongly lustrous, dorsal surface more or less uneven, sides rather semihyaline. Legs not robust.

Wings pale brownish, thin and semitrans-
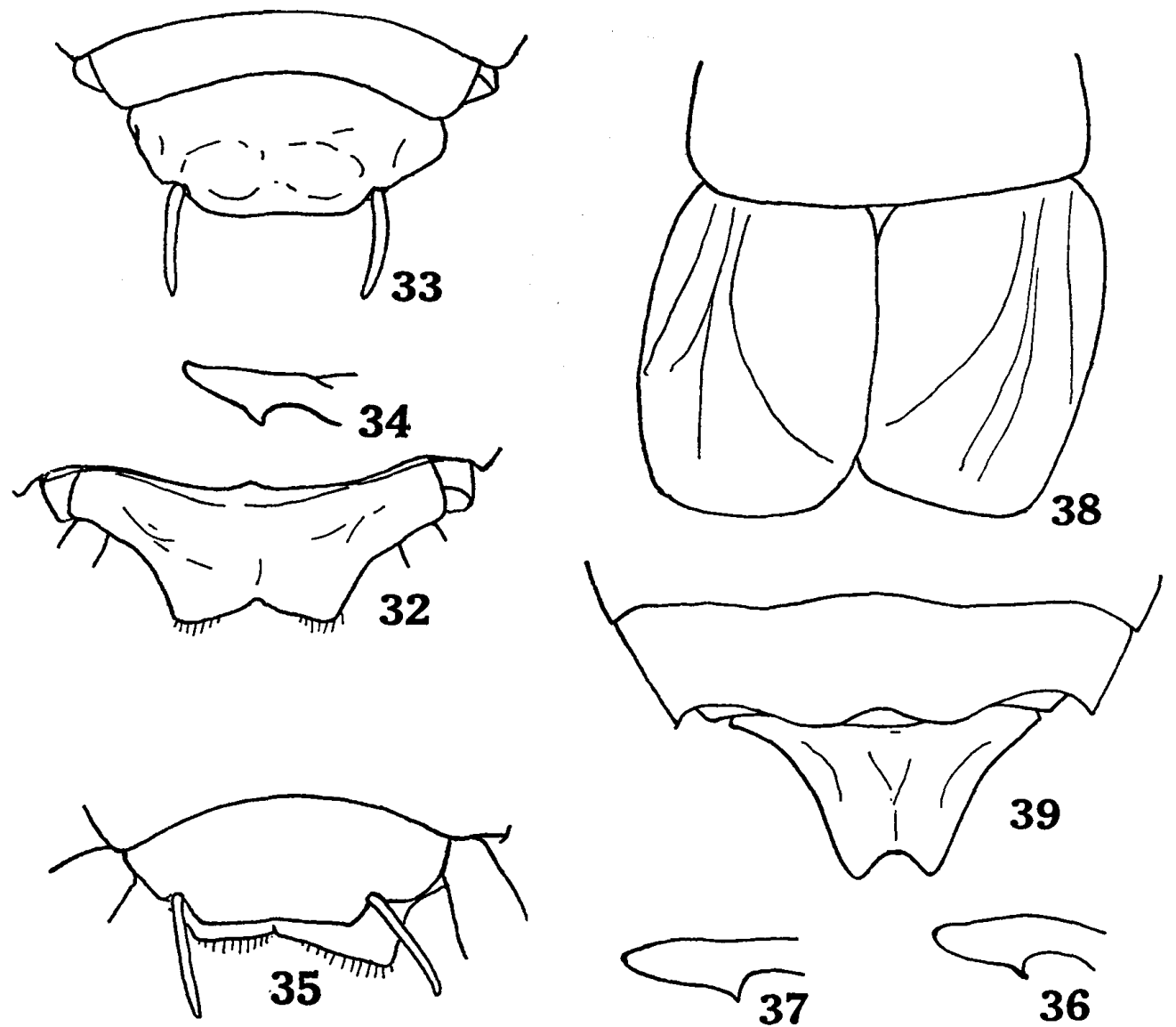

Figs. 32-39 Periplaneta formosana, Taiwan

32: 今 Supra-anal plate, dried specimen, 33 : Hypandrium, 34, 36, 37: Apex of left phallosome, Taihoku (34), Ranrun (36), Kosun (37), 35: ㅇ Abdominal end, ventral, 38: 우 Forewing, Type specimen, 39: 우 Supra-anal plate, Type specimen 
parent, not shining.

Abdomen flat and concolorous, supra-anal plate broadly bilobed (Fig. 48). Hypandrium with smoothly waved distal end, the styli are rather fine. In one specimen which is large in body size, the hypandrium is more angular at the sides (Fig. 52) when treated by $\mathrm{KOH}$.

Left phallosome with peculiar end, the apex pointed (Figs. 50, 53).

Remarks: Shiraki illustrated the peculiar shortened female wings but nothing of the male. Since any female specimen was not accessible to us our identification may not be very final!

\section{Periplaneta ceylonica Karny}

Periplaneta ceylonica Karny, 1908, p. 18 \$ (key only!)
Periplaneta ceylonica: Princis, 1951, p. 89, Figs. 1-3 (ई supra-anal plate, subgenital plate, left phallosome) " 1 of Indien (British Museum)"

Periplaneta ceylonica: Princis, 1952, p. 41 (Arten die zu streichen sind)

Periplaneta fallax: Bey-Bienko, 1957, pp. 903-904, Fig. 2 (o supra-anal plate) "Yunnan, Tszinpin, 1,200 m, 30. V.1956, 1ิ (D. Panfilov)"

Periplaneta ceylonica: Princis, 1966a, pp. 44-45 "Untersuchtes Material : ô (Holotypus von Ceylon), Ceylon, Paradenia, No. 5664 ex Coll. Brunner v. W. (Mus. Wien); 3 of of Ceylon, Kandy, 13 bzw. 19 bzw. 25.XI.1953, F. Keiser leg. (Mus. Basel) ; ô Ceylon, Kandy, L. Horton's Drive, 4.XI.1953, F. Keiser leg. (Mus. Basel) "'
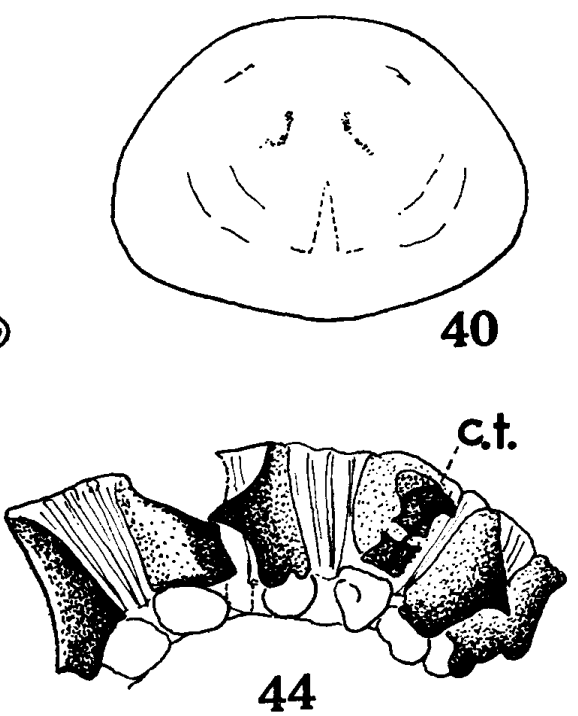

Figs. 40-44 Periplaneta sp. 令, Wulai, Taiwan, alcoholic

40: Prothoracic tergite, 41 : Supra-anal plate, 42 : Hypandrium, $43:$ Apex of left phallosome, 44: Gizzard armature (c. t. : constricted tooth)
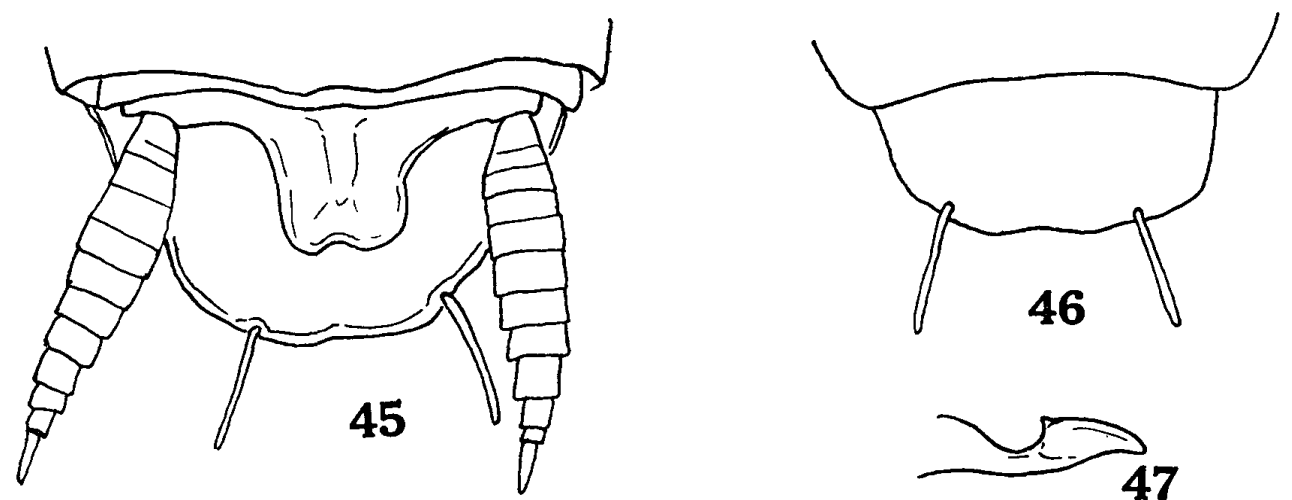

Figs. 45-47 Periplaneta uenoi, 今 Wushe, Taiwan

45: Abdominal end, dorsal, 46: Hypandrium, 47: Apex of left phallosome 
Periplaneta ceylonica: Princis, 1966b, p. 445 "China, Indien, Ceylon"

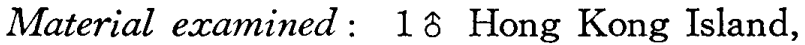
1962, leg. D. J. Romer; 1 우 (Allotype) Peak, Hong Kong Island, 27.IV.1963, leg. D. J. Romer.

A robust species among this group, with deep brownish body. Undescribed female is brachypterous.

of Body $25 \mathrm{~mm}$, forewing $27 \mathrm{~mm}$.

Head deep brownish, no particular marking present excepting pale ocellar spots. Prothoracic tergite broad and shining, no wavy depression; legs robust, tarsal arolia moderately developed. Both wings well developed, entirely brownish, paler in the anal field of hindwings.

First abdominal segment with median secretory opening surrounded by a conspicuous tuft of hairs. Supra-anal plate developed into paired round lobes, margined with bristles (Fig. 55). Hypandrium ending in a round head, styli long. The distal end of left phallosome ending in a curved, broad head with a recurved hook (Fig. 57).

ㅇ (Allotype) A mature specimen. Body $26 \mathrm{~mm}$, forewing $7 \mathrm{~mm}$, entirely chestnut brown.
Head entirely deep reddish brown with yellowish ocellar spots.

Prothoracic tergite broad, width $10 \mathrm{~mm}$, broadest in the behind. Legs robust with strong tibial spines. Forewing abbreviated as Fig. 58, distal end rather straightly cut, entirely deep reddish brown.

Abdomen also deep brown, the supra-anal plate ending somewhat to semitubular piece, divided at the end, but covered by the extended lobe of 9 th tergite at the base (Fig. 59).

Remarks: The structure of abdominal end and the left phallosome of our Hong Kong specimen agrees well with the same of Princis' pictures (1951). According to him this species ranges rather widely in Ceylon, India, and Southwest China, but the female insect has never been described. Only one pair of this important species was obtained by Mr. J. D. Romer.

\section{Periplaneta karnyi (Shiraki)}

Ischnoptera formosana Karny, 1915, 102 "Taihanroku , 1ㅇ”"

Periplaneta karnyi (Shiraki), 1931, p. 182 nom. nov.

Hebardina karnyi : Princis 1966b, 465 "For-
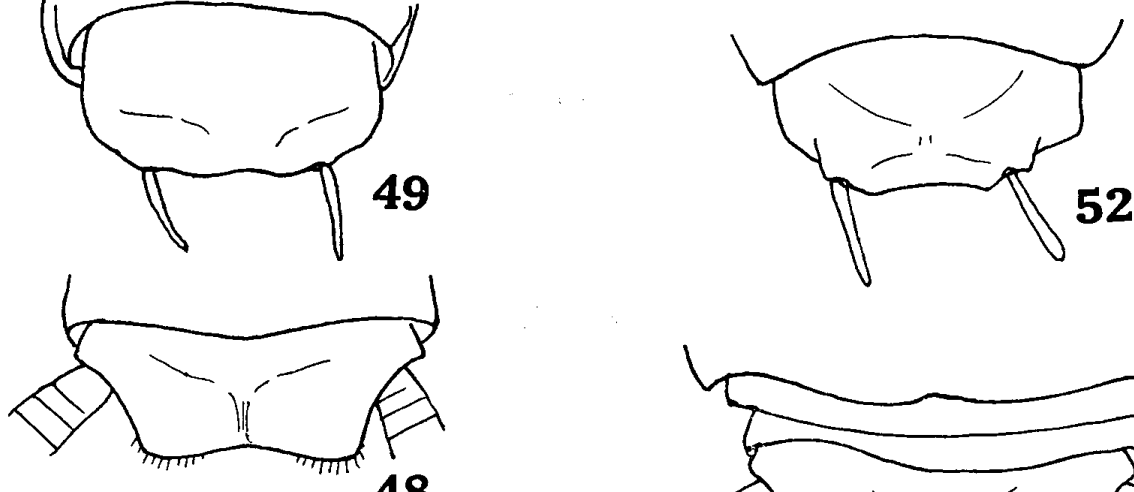

48

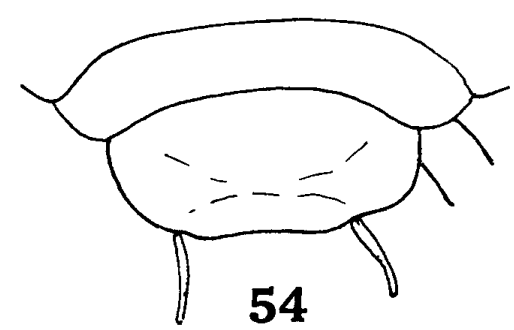

Figs. 48-54 Periplaneta arisanica 令 Taiwan, Tattaka (48-50), Fen-ch'i-hu (51-54) 48: Supra-anal plate, 49: Hypandrium, 50 : Apex of left phallosome, 51 : Supra-anal plate, $\mathrm{KOH}$ treated, 52: Hypandrium, $\mathrm{KOH}$ treated, 53: Apex of left phallosome, 54: Hypandrium, dried specimen 
mosa",

This is a small species, and Karny's single type female specimen which has rather shortened wings and abdomen was entirely misidentified by him as an "Ischnoptera." It is interesting to note that Karny even stressed that "Von den übrigen Ischnoptera-Arten durch die kürzeren Flugorgane und die eigentümliche Form des weiblichen Subgenitalplatte leicht zu unterscheiden."

Shiraki (1931, p. 182) examined the type specimen and removed it from Ischonoptera to Periplaneta but mentioned nothing.

Material examined: 1 우 (Holotype) Taihanroku, Formosa, H. Sauter, "Ischnoptera formosana Karny," "Karny det.," "Deutsch. Entom. Inst., Berlin," "7.

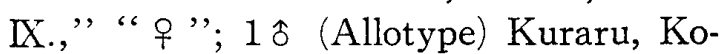
shun, 2.IV.1965, leg. T. Shirozu; 1 ㅇ ditto, (both taken in copula!); $1 \hat{\text { }}$ Kanchanaburi, Thailand, 8.X.1975, leg. H. Kurahashi; 1 ô Cap St. Jacques, Prov. de Phuoc Tuy, Sud Vietnam. 3.VI.1962, leg. Sadanobu Inoue.

ô Body $19 \mathrm{~mm}$, forewing $15 \mathrm{~mm}$. A small flat-bodied, entirely pale brownish insect.

Head entirely pale brownish, ocellar spots are obscured in this specimen. Prothoracic

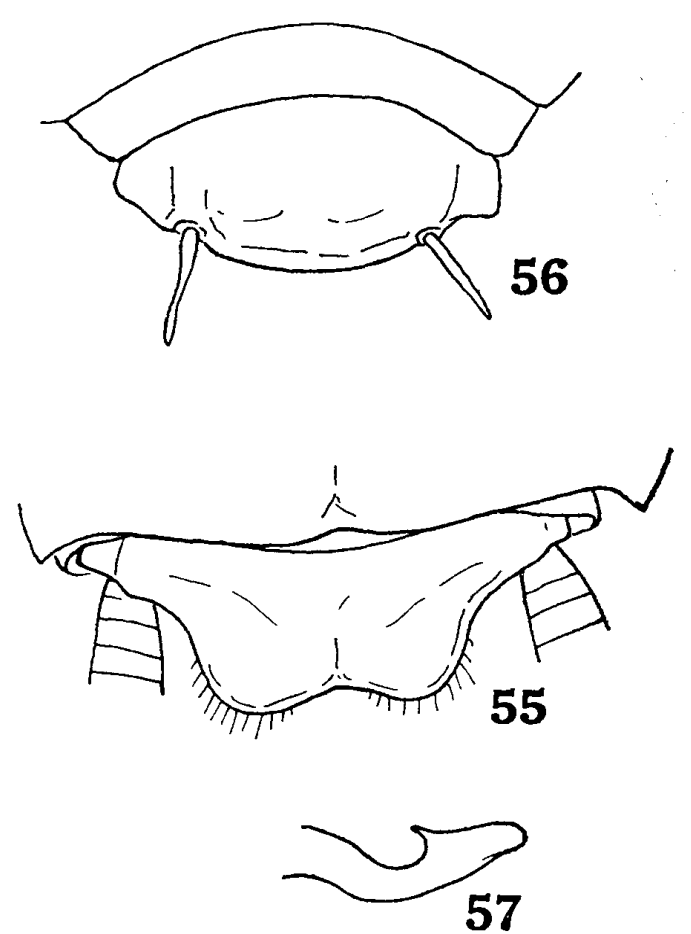

tergite transverse, very broad, forewing normal, apices well beyond the abdominal end when closed.

First segment of abdomen with median secretory pit covered with the tuft of hairs. Distal margin of supra-anal plate divided into two lobes, the hypandrium also into two pieces with a narrow depression (Fig. 61). The end of left phallosome iron-shaped (Fig. 62).

우 Body $14 \mathrm{~mm}$ (Type), $21 \mathrm{~mm}$ (Kuraru specimen), forewing length $9.5 \mathrm{~mm}$ (Type), $8 \mathrm{~mm}$ (Kuraru specimen).

Body coloration more or less deeper than that of male. Prothoracic tergite broader, $5.5 \mathrm{~mm}$. Forewing more or less roundly abbreviated, but not squarely cut. Hindwings present and similarly shortened as the forewings, never degenerated. The supra-anal plate as Figs. 68, 69, divided at the end.

Remarks: These 1 s 1 우 now treated are all the specimens hitherto collected by us. Dr. Shirozu was fortunate enough to find a pairing couple of this species which is very much allied to the following Southeast Asiatic species.

\section{Periplaneta floweri Hanitsch}
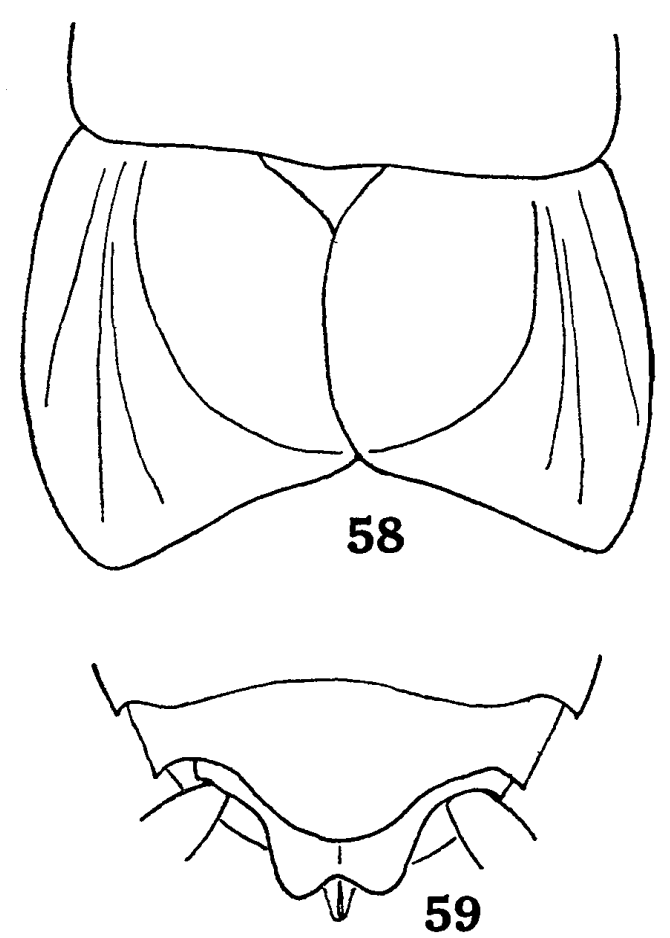

Figs. 55-59 Periplaneta ceylonica, Hong Kong, dried specimens

55: 古 Supra-anal plate, 56: Hypandrium, 57: Apex of left phallosome, 58: 우 Forewings, 59: 우 Supra-anal plate 
Periplaneta floweri Hanitsch, 1931, 386, 400

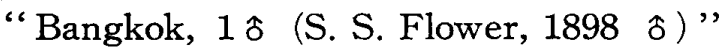
Periplaneta floweri: Hanitsch, 1932a, p. 5 " 1 example (sex? abdomen missing), Medan, 1921-6"

Periplaneta floweri: Hanitsch, 1932b, 51, 75 " 1 o Siboga, Sumatra, Oct.1890-March, 1891, E. Modigliani," "I have also before me a $\hat{o}$, from Pulo Tioman (V. Knight, June 1915) and another $\hat{o}$, from the Lang Kawi Is. (H. M. Pendlebury, April, 1928)"

Periplaneta floweri: Bruijning, 1948, 39, 112 "Amsterdam Mus. : Medan, Sumatra, J. B. Corporaal, Sept.1920, 1 o”

Periplaneta floweri: Princis, 1966b, p. 456 "Siam, Sumatra"

Material examined: 1 o Chiengmai, Thailand, 16. II.1958, leg. H. Ikoma; 1 ㅇ ditto, 26.V.1958 (Allotype); $1 \hat{\text { o Khao }}$ Chong, S. Thailand, 23. V.1965, leg. Y. Miyatake.

of: Body $16.0-16.5 \mathrm{~mm}$, forewing 15.0 $15.5 \mathrm{~mm}$. Flat-bodied, pale brownish species.

Head light brown, the ocellar spots whit- ish. Prothoracic tergite broad, $5.0-5.5 \mathrm{~mm}$. Forewings broad, and broadly rounded at the end. The supra-anal plate and hypandrium as Figs. 71, 72, 74, 75. The end of left phallosome was examined with North Thai specimen (Fig. 73), which allies to that of the preceding species.

우 : Body $15 \mathrm{~mm}$, forewing $10 \mathrm{~mm}$. Body as that of the male but the wings are shorter (Fig. 76), and generally deeper in colour. The supra-anal plate as Fig. 76, slightly deeper divided at the end.

Remarks: As supposed by Hanitsch (1932, Sumatra), this species is very closely allied to karnyi Shiraki, but may be separated from it by the shape of supra-anal plate in both sexes. The female is now described for the first time.

\section{Periplaneta banksi Hanitsch}

Periplaneta banksi Hanitsch, 1931, 386, 401 우 "Philippines, 1 우 (C. S. Banks, 1908),"

"Exceeding in size all other oriental species of Periplaneta"

Periplaneta picea: Karny (nec Shiraki, 1906),
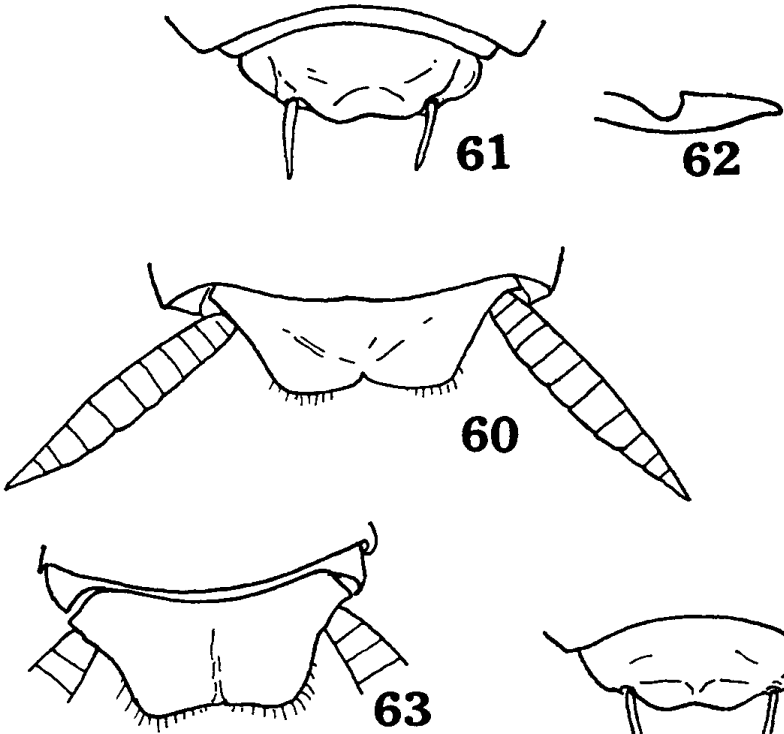

63
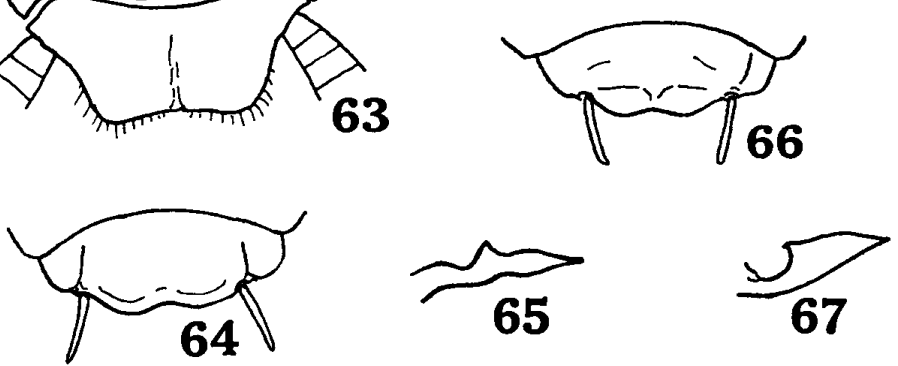

Figs. 60-70 Periplaneta karnyi, dried specimens, Koshun, Taiwan (60-62, 68), Kanchanaburi, Thailand, KOH treated $(63-65)$, S. Vietnam $(66,67)$, Taihanroku Sauter. leg. Type (69)

60, 63: 疋 Supra-anal plate, 61, 64, 66: Hypandrium, 62, 65, 67 : Apex of left phallosome, 68, 69: 우 Supra-anal plate, 70: Gizzard armature (c. t. : constricted tooth)
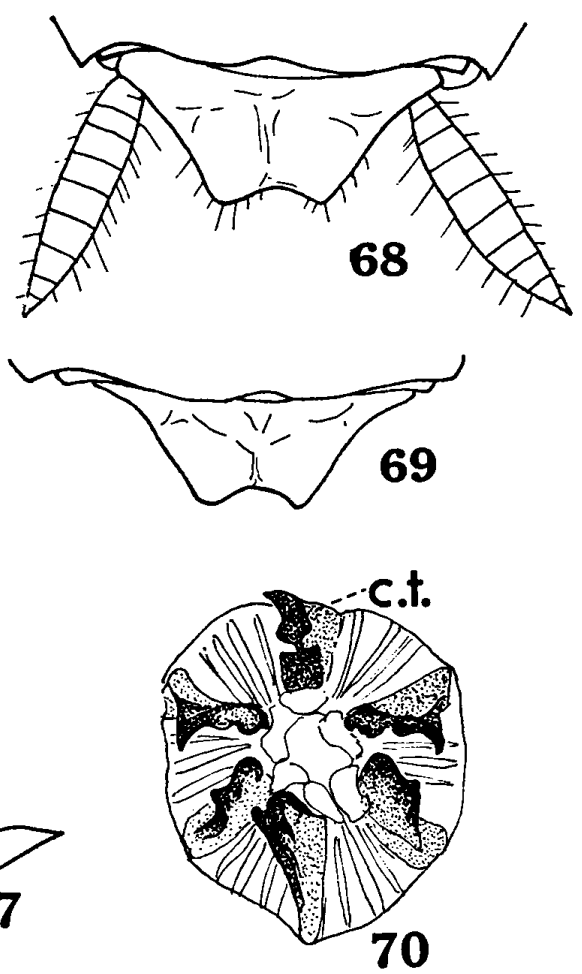


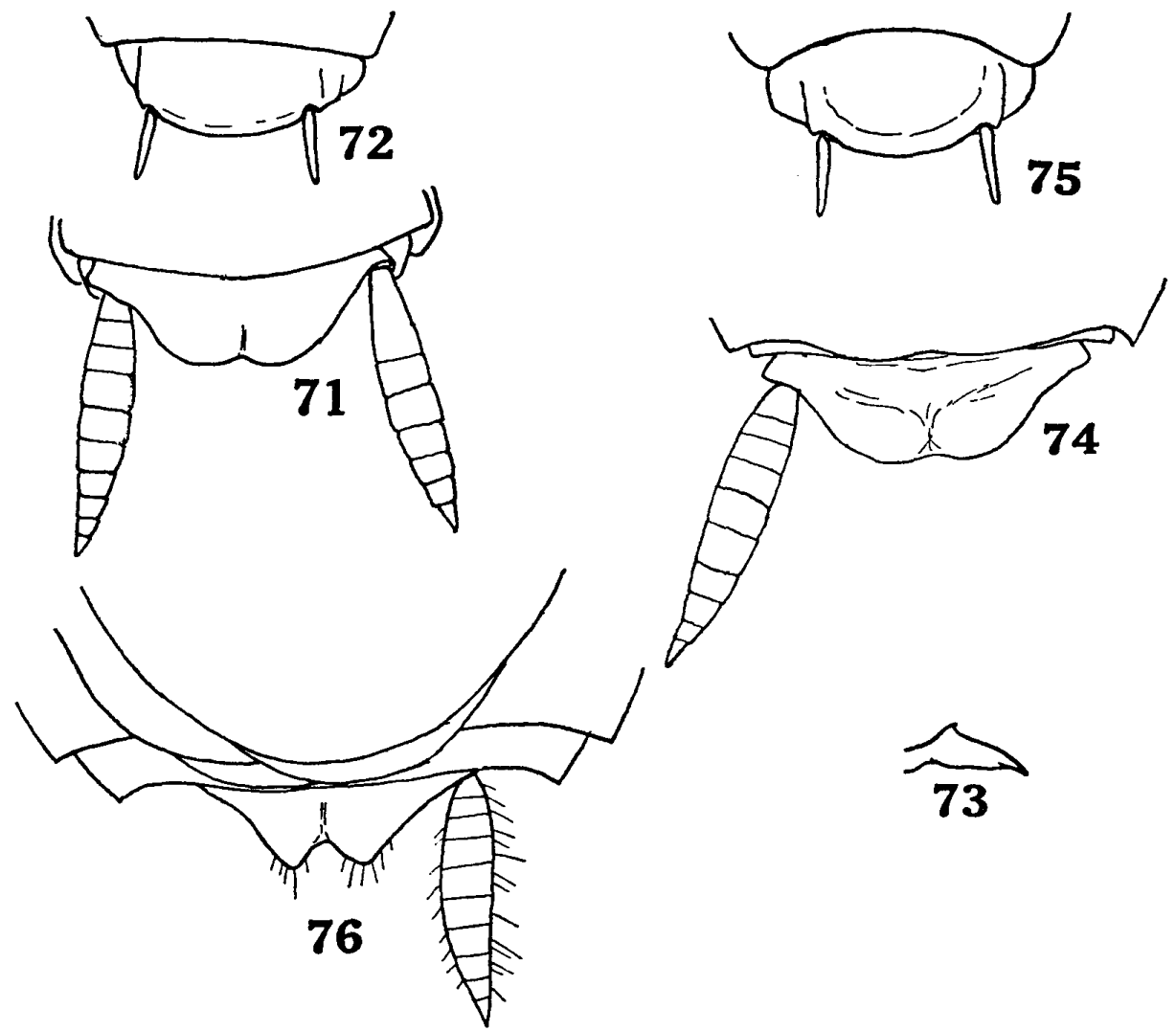

Figs. 71-76 Periplaneta floweri, Thailand, Chiengmai (71, 72, 73, 76), Khao Chong, Thailand $(74,75)$, dried specimens

71, 74: 今 Supra-anal plate, 72, 75: Hypandrium, 73: Apex of left phallosome, 76: 우 Abdominal end, dorsal

1915, p. 62, 97 " Fuhosho, VII.1909, (1§) 3 우 우 Hoozan, 1910, 1 larve (우)" (!)

Periplaneta banksi: Bruijning, 1948, 110

"Leiden Mus. : Sinabang, Sumatra, J.

B. Corporaal, 1913, 1 ㅇ"

Periplaneta banksi: Princis, 1966b, p. 441

"Formosa, Philippinen, Sumatra (?)"

Material examined: 1 우 Fuhosho, Formosa,

Sauter, VI.1909, क Karny det., Coll.

Inst. Pflanzenschutzf., Eberswalde ; 1

left forewing Kenting, S. Taiwan, 22.

IV.1971, N. Fukuhara, Coll. Nat. Inst.

Agr. Sci. Tokyo.

It is curious that Karny (1915) identified this huge cockroach species to be Periplaneta picea Shiraki (=fuliginosa!). Shiraki (1931) said nothing about this. Princis (1966b) placed this insect under Philippine banksi Hanitsch (1931). But Bruijning (1948), judging from the description, noted the similarity of this species with Malaysian $P$. regina Saussure (1864). Unfortunately the male insect of banksi has never been described.

o ad. Body $38 \mathrm{~mm}$, forewing $37 \mathrm{~mm}$.
Width of prothorax $14 \mathrm{~mm}$. A gigantic, robust insect, body entirely shining chestnut brown.

Head brownish, paler below the level of antennal bases, ocellar spots whitish. Antenna short, about $30 \mathrm{~mm}$. Prothoracic tergite broad, without any depression. Wing apices reaching well beyond the abdominal end, therefore this species is exceptional to the others treated in this paper. Legs ro-

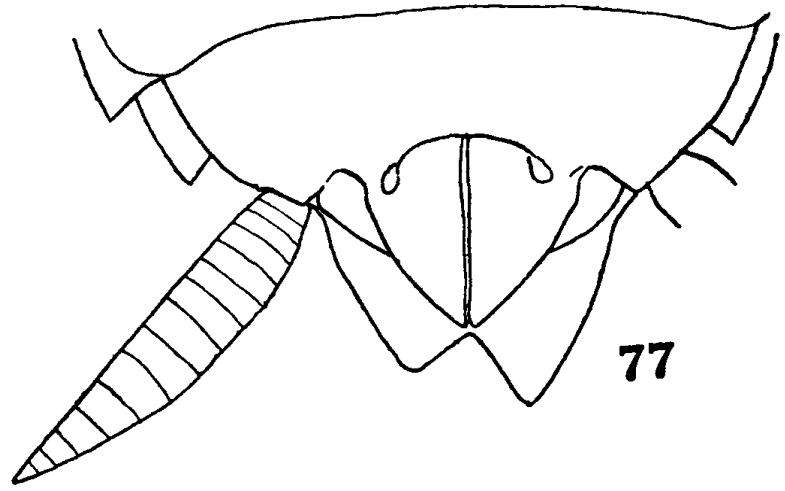

Fig. 77 Periplaneta banksi, 우 dried specimen, abdominal end, leg. Sauter 
bust and spiny, the tarsal arolia moderately developed.

Abdomen broad and robust, supra-anal plate deeply divided (this part is asymmetrical in this specimen). The ovipositor valve is well developed (Fig. 77).

Remarks: A detached forewing now obtained by Mr. Fukuhara is very long, measuring $45 \mathrm{~mm}$ (Fig. 18). Therefore it is larger than the Sauter's specimen. Does this forewing belong to a male insect?!

\section{Notes on the genus Cartoblatta}

Concerning these sexually dimorphic Periplaneta species mention should be made about the genus Cartoblatta Shelford (1907).

In his World Catalogue of Blattaria Princis (1966b) placed several Asiatic Periplaneta, including formosana Karny and arisanica Shiraki here treated, in the genus Cartoblatta. Later Bey-Bienko (1969) also used this name for two Asiatic species.

Originally Cartoblatta is established by Shelford (1907) to include African species. His original generic definition is as follows:

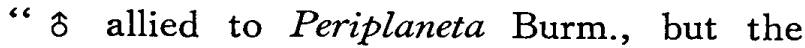
pronotum is transversely elliptical, anterior border truncate, posterior border slightly produced. Tegmina and wings considerably longer than the body. Mesonotum and metanotum without long backwardly-directed processes. No scent gland opening on first abdominal tergite."

" o With the tegmina short, quadrate, not covering the first abdominal tergite. Sixth and seventh abdominal tergites slightly declivous, seventh tergite not covered by the sixth" (Pl. 2, Fig. 4. ㅇ entire insect).

His later definition (1910) is: "Allied to Blatta Linnaeus and Pseudodelopeltis Krauss. Pronotum ( $\hat{\delta}$ ) transversely elliptical, its anterior border truncate, the posterior border slightly produced. Meso- and metanotum ( $\hat{o})$ without backwardly directed membraneous processes. Tegmina and wings ( $\hat{o}$ ) considerably exceeding the apex of the abdomen. Tegmina ( 9 ) short and quadrate, not covering the first abdominal tergite, their sutural margins touching; wing rudiment present. No scent-gland opening on dorsum of abdomen ( $\hat{o})$. Tarsi as in Blatta." "Type- species C. pulchra Shelford, East Africa (1907).",

From these definition it is clear that two Taiwanese species cannot be placed in Cartoblatta since the males of both species now supposed have evident secretory pit on the first abdominal segment.

\section{ACKNOWLEDGEMENT}

In accumulating the material I owe greatly to the kind cooperation of the following entomologists: Mr. Narao Fukuhara, Mr. Sadanobu Inoue, Mr. Hiroshi Ikoma, Dr. Rokuro Kano, Dr. Hiromu Kurahashi, Mr. Yorio Miyatake, Dr. Takashi Shirozu, Mr. Hiroshi Suzuki, Dr. Syun'iti Ueno, Mr. J. D. Romer (Urban Services Department, Hong Kong). In checking Karny's type specimens I am indebted to Dr. K. K. Günther, Berlin, and the authorities in the Institut für Pflanzenschutzforschung, Eberswalde, for their kind offices. I also owe greatly to Prof. Y. I. Chu in examining the Shiraki's type specimens preserved in the National Taiwan University.

\section{REFERENCES}

Asahina, S. (1967): The cockroaches of the genus Rhabdoblatta of Japan, the Ryukyus and Taiwan. Jap. J. Med. Sci. Biol., 29(5): 425-442.

Asahina, S. (1977): Blattaria or cockroaches of Amamioshima, In Animals of Medical Importance in the Nansei Islands of Japan, pp. 99105, Tokyo.

Bey-Bienko, G. Y. (1957) : Blattoidea of Szechuwan and Yunnan, I. Rev. Entomol. URSS, 36 (4): 895-915 (in Russian with English summary)

Bey-Bienko, G. Y. (1969): New genera and species of cockroaches (Blattoptera) from tropical and subtropical Asia. Rev. Entomol. URSS, 48 (4): 831-862. (in Russian)

Bruijning, C. F. (1948): Studies on Malayan Blattidae. Zool. Meded., 29 : 1-174.

Hanitsch, R. (1931): On a collection of Malayan Blattidae from the British Museum (Nat. Hist.). Ann. Mag. Nat. Hist., 7 (10) : 385-408.

Hanitsch, R. (1932a) : On a collection of Blattids from the East Coast of Sumatra. Misc. Zool. Sumatrana, $42: 1-8$.

Hanitsch, R. (1932b): Beccari and Modigliani collection of Sumatran Blattidae in the Museo Civico Genoa. Ann. Mus. Civ. St. Nat. Genova, $56: 1-45$.

Karny, H. (1908): Wissenschaf tliche Ergebnisse 
der Expedition Filchner nach China und Tibet, 1903-1905, X (I), I Abs. Zoologische Sammlungen, 1. Blattaeformia, pp. 14-22.

Karny, H. (1915) : H. Sauter's Formosa Ausbeute, Orthoptera und Oothecaria. Suppl. Entomol., 4 : 56-104.

Princis, K. (1951) : Kleine Beiträge zur Kenntnis der Blattarien und ihrer Verbreitung, IV. Opusc. Entomol., 16 : 89-93.

Princis, K. (1952): Kritisches Verzeichnis der Blattarien Chinas und Tibets. Opusc. Entomol., 17 : $33-44$.

Princis, K. (1966a) : Kleine Beitrage zur Kenntnis der Blattarien und ihrer Verbreitung, IX. Opusc. Entomol., 31 : 43-60.

Princis, K. (1966b) : Orthopterorum Catalogue, Pars 8, In Blattidae-Nocticolidae, pp. 401-614.

Shelford, R. (1907): Sjöstedt's KilimandjaroMeru Expedition, Blattidae, pp. 13-48, 2 pls.

Shelford, R. (1910): Genera Insectorum, Fasc. 109, Blattidae-Blattinae, 27 pp., 2 pls.

Shiraki, T. (1905/06): Neue Forficuliden und Blattiden Japans. Trans. Sapporo Nat. Hist. Soc., $1(2)$ : 1-14.

Shiraki, T. (1931) : Orthoptera of Japanese Empire, II. Blattidae. Insecta Matsumurana, 5 (4) : 171-209.

\section{摘 要}

琉球・台湾・香港・タイ国より得られた野棲 Periplaneta 属ゴキブリ類の分類

1977 年筆者が奄美大島産の 1 号によって 命名記載し た P. suzukii スズキゴキブリは，その後に今が得られ たのでそれを記載した。他にこのような早短翅・古長翅 のPeriplanetaについては, 台湾, 香港, タイ国などより の資料が得られたので，あわせてここに同定記載した. さらにこれらの種とアフリカより知られている Cartoblatta 属との関係についても考察した.

なおこれらの種類は最後の banksi を除いて，いず れも今長翅早短翅であるので, 全体をフタガタゴキブリ 群として扱い，各種には次のような和名を与えておきた 认.

P. suzukii Asahina スズキゴキブリ(朝比奈, 1977), P. formosana Karny タイワンゴキブリ (新称), $P$. uenoi nov. ウエノゴキブリ (新称), P. arisanica Shiraki アリサンゴキブリ(新称), P. ceylonica Karny セイ ロンゴキブリ (新称)，P.karnyi (Shiraki) カルニーゴ キブリ(新称)，P. floweri Hanitsch フロワーゴキブリ (新称)，なお P. banksi Hanitsch にはバンクスゴキブ リ(新称) としておく.

\section{チビゴキブリ四国に産す \\ Anaplectella ruficollis taken in Shikoku}

チビゴキブリ科 Anaplectidae のゴキブリは熱帯・ 亜熱帯の昆虫であって，本邦からはただ 1 種，Anaplectella ruficollis (Karny) が八重山諸島と奄美諸島か ら知られていた (Asahina, S. : 衛動, 28(3), p. 275, 1977).

今回,石井 孝教授から同定を依頼された徳島県産標本
中に 1 ㅇ発見したのでここに記録しておく.これは石 井教授が1979年 6 月 10日, 徳島県石井町にある墓地のマ ツ（独立樹）を雳煙した際に得られたもので，他に多数 のヒメクロゴキブリ Chorisoneura nigra(Shiraki) と, 若干のモリチャバネゴキブリ Blattella nipponica Asa. hina があった。

(朝比奈正二郎) 